\title{
Perspectives of Saudi EFL Learners towards Teacher Response in Writing Courses
}

\author{
Fahad Alqurashi ${ }^{1}$ \\ ${ }^{1}$ Umm Al-Qura University, Makkah, Saudi Arabia \\ Correspondence: Fahad Alqurashi, Umm Al-Qura University, Makkah, Saudi Arabia. E-mail: \\ fmqurashi@uqu.edu.sa
}

Received: April 25, 2015 Accepted: July 11, 2015 Online Published: September 29, 2015

doi:10.5539/ijel.v5n5p37 URL: http://dx.doi.org/10.5539/ijel.v5n5p37

\begin{abstract}
The purpose of this study is to explore the perspectives of 86 Saudi EFL freshmen towards their teachers' response to their writing. The participants' input has been collected via a questionnaire to shed light on the factors that influence students' attitudes about writing in English as a foreign language. The study found that the students were willing to read their essays again after the teacher commented on them which could be a sign that they realized a great value in their teacher's written comments. The participants asserted that they thought carefully about the teacher's comments and corrections which might be taken as an indication that those students considered their teacher response a great help to gain confidence in themselves as good writers. In addition, they mentioned that they paid more attention to teacher response on both surface-level errors and meaning-level errors. This was perhaps due to response effectiveness in helping them produce better writing with less mistakes. The participants also mentioned that all types of teacher response were important to them which could indicate positive attitudes toward such response on their writing and its role in developing the necessary skills to improve their writing proficiency. The study recommended that writing teachers should utilize feedback to student writing as a motivating factor to help students revise their drafts by providing focused and clear response, not over-stressing the correction of errors, and enhancing the feedback value with student-teacher conferences. Teaching conditions should be improved by reducing the number of students in writing classes and reducing other work obligations.
\end{abstract}

Keywords: EFL writing, Saudi, teacher response

\section{Introduction}

Writing is one of the most important skills that students of English as a second language (ESL) or English as a Foreign Language (EFL) need to develop in order to enhance their efforts to learn the target language and elevate their L2 proficiency. Writing well means displaying an ability to convey ideas and facts using clear, accurate and appropriate written language (Hashim, 2011). Efficient "teaching of writing" has become one of the most difficult tasks for ESL/EFL teachers as it involves multiple processes. Composition teachers in ESL/EFL contexts have been praised for playing "several different roles, among them coach, judge, facilitator, evaluator, interested reader, and copy editor" (Reid, 1993, p. 217). Offering constructive feedback to students is a crucial part of efficient teaching that has a great impact on students' ability to produce quality writing. Researchers in composition studies consider teacher response to student writing a significant pedagogical means that provides critical information to students about their writing performance (Zamel, 1985). A more exhaustive view maintains that teacher response can come in different forms, from different readers, and at different stages of the writing process with the intention of improving students' writing with feedback which "includes all reactions to writing, formal or informal, written or oral, from teacher or peer, to a draft or final version" (Freedman, 1987, p. 5).

Teacher response to student writing is a basic element in the process-oriented approach to writing where the focus of teaching writing has shifted from product to process (Applebee, 1986; Jacobs \& Farrell, 2001). This means that instead of looking at the final product of students' writing, teachers look at their writing process instead of simply grading the final product. This approach emphasizes the importance of the teacher working with the students to overcome difficulties encountered during the writing process and providing tools needed to overcome the obstacles that confront them while writing. Many activities in the development of the writing process approach involves students and teachers working together. The focus is to help student writers to generate and organize ideas, express themselves, write multiple drafts, receive feedback from teachers and other students, and revise their 
writing before turning in assignments (Scane et al., 1991; Myles, 2002). Previous research in composition studies found teacher response to be a basic element in the writing process that plays a central role in learning the skill of composition. Effective teacher response provides multiple advantages for writing students including:

- Teacher response to student writing is an important component of the formative assessment process that gives information to teachers and students about how students are doing relative to classroom learning goals (Brookhart, 2008);

- Learners can utilize teacher response to determine for themselves whether they are performing well or not (Mi, 2009; Littleton, 2011);

- In the case that students are not performing well, teacher response helps them to take corrective action in order to improve their performance and avoid repeating mistakes (Getchell, 2011);

- Teacher response helps students to monitor their progress, encourages them to accept others' opinions and tolerate critical remarks (Asiri, 1996);

- Responding to student writing helps teachers to diagnose their students' problematic areas and assess their progress in learning the written language (Hino, 2006);

- Teacher response was found helpful to make students more conscious of the recursive nature of the writing process, motivate students to write multiple drafts and revise their writing several times in order to produce a much improved piece of writing (Russell \& Spada, 2006).

\section{Students' Reactions to Teacher Response}

Teachers' written feedback constitutes the most commonly used form of feedback that students receive to their writing assignments. The impact and efficacy of written teacher responses to students' writing have been investigated in several studies (e.g., Sommers, 1982; Zamel, 1985; Hamp-Lyons \& Chen, 2001) and the attitudes of students towards their teachers' written feedback and how they respond to such feedback have been the focus of other studies (e.g., Cohen, 1987; Ferris, 1995; Hyland \& Hyland, 2006). These studies revealed that attention to students' reactions to their teachers' feedback is a critical factor that influences the usefulness of the given feedback. Focusing on students' reactions to teachers' feedback promotes a high level of interaction that transcends the dominating non-contextual and non-social view of teacher response which "focused largely on texts and conducted within a linear model of teacher respond and student revise" (Goldstein, 2001, p. 77). The authors of studies that highlighted the significance of students' reactions to teachers' feedback adopted a socio-cultural view that considers learning and teaching social activities rather than cognitive ones (Lantolf, 2000; Block, 2003; Prior, 2006). This 'social turn' marks a paradigm shift in learning and teaching from the cognitive approach that is "too narrow in its understanding of context and was eclipsed by studies that attended to social, historical, and political contexts of writing" (Prior, 2006, p. 54) to the socio-cultural approach that "offers what is lacking in much literature on education - an effective conceptual metaphor for the quality of teacher intervention in learning" (Hammond, 2002, p. 2).

Early studies in the field of ESL/EFL writing that investigated student perspectives to teacher response emerged in the 1990s and indicated that students attach more value to teacher feedback than other forms of feedback, such as audio feedback, peer evaluation, and self-evaluation (Leki, 1991; Saito, 1994; Zhang, 1995). Some studies found that L2 students were willing to receive feedback on both the form (grammatical, lexical, and mechanical features) as well as the content and style of their writing (Hedgcock \& Lefkowitz, 1994; Oladejo, 1993). The findings of some other studies showed that L2 students who place a high premium on accuracy in writing wished their teachers to point out and correct every error in order to help them produce error-free writing (Lee, 2005; Leki, 1991). Some researchers reported that many surveyed students faced difficulty in understanding the teachers' feedback and found their corrective comments to be vague and confusing (Cohen, 1991), while other researchers found that their students used a range of strategies in dealing with teachers' responses such as discussing the corrective comments with their teacher or friends, consulting grammar books and dictionaries, or doing nothing (Ferris, 1995). In addition, studies on teacher response showed that some L2 students prefer indirect (implicit), corrective feedback and want the teacher to indicate the error without providing the correct form (Arndt, 1993; Hyland, 2001; Saito, 1994) while some other learners prefer direct (explicit) corrective feedback and want the teacher to provide the correct form (Ferris, 2003; Lee, 2005).

There are several studies that examined Saudi EFL students' perspectives on the feedback that they received from their writing teachers. For example, Grami (2005) found that Saudi college students showed profound interest, appreciation and enjoyment towards their teachers' feedback, thought it was important for their progress, and expected teachers' written feedback to help them improve their surface-level errors. Mahfoodh and Pandian (2011) 
conducted a qualitative case study to investigate Saudi EFL students' affective reactions and perceptions of their teachers' written feedback. The participants perceived their teachers' written feedback as useful and very important for the development of their writing skills and wanted their teachers to focus on all aspects of written texts when they provide written feedback. The study concluded that there were contextual factors that had an impact on students' affective reactions and perceptions of their teachers' written feedback such as their past experiences, teachers' wording of written feedback, students' acceptance of teachers' authority, and teachers' handwriting. Mustafa (2012) conducted another qualitative case study on a small sample of Saudi students (3 males and 2 females) in a private ESL school in Vancouver, Canada. At the time of data collection, those students attended two different classes: 1) mainstream ESL classes that were multicultural in nature; and 2) power writing classes that were tailored for the Saudi students. The findings suggested that those five Saudi students did not think highly of their teachers' responses and felt that the feedback they desired was prominently different from what they received.

\section{The study}

\subsection{Purpose, Setting, and Participants}

The current study was conducted in the academic year of 2013/2014 with the aim of exploring the views of Saudi students who learn English as a foreign language toward teacher comments on their writing. The students' perspectives were significant indicators of their attitudes about the difficulties they face in writing in the target language (Myles, 2002). Attitudes towards learning have been considered as an integral part of the learning process that has its impact on second/foreign language learning pedagogy (Ababneh, 2012). Analyzing students' perspectives is important for educators and policy makers to understand students' preferences for the learning process (Banya \& Cheng, 1997). It is expected that the results of this research project will contribute to pinpointing some difficulties that hinder the students' progress in mastering basic writing skills. The results will also help educators to reevaluate teaching methods and create necessary changes to improve classroom environments in order to make the process of feedback-giving more accurate and focused and the process of feedback-receiving more effective and beneficial.

The subjects participating in this study were 86 male freshmen enrolled in four sections of the course Writing I which was a requirement of the English bachelor of arts program at Umm Al-Qura University, Makkah, Saudi Arabia. It is a four-year program which consists of 94 hours of course work taught in the English language in addition to 36 hours of courses taught in Arabic. Upon their admission to the English BA program, freshmen take four, three-credit courses that cover the basic learning skills: listening, grammar, reading, and writing. Each course met twice a week with a 100-minute lecture at the beginning of the week and a 50-minute lecture in the middle of the week. The textbooks used in those courses were a four-skill comprehensive ESL/EFL series that combined communicative activities with skill-building exercises to enhance students' academic success. The series introduces integrated themes across proficiency levels that are articulated across skill strands to prepare students for more challenging academic content.

\subsection{Procedures \& Data Collection}

In the Writing I course, students are introduced to the basic steps of composition at the paragraph level. In the early stages, teachers review different techniques of sentence formation. For example, in chapter one, School Life Around the World, there are exercises on how to use 'also' to introduce additional information, 'but' to introduce contrasting information, and 'so' to introduce a result. Students are required to understand terms are used to combine sentences in order to enhance their ability to write well-formed paragraphs. Upon mastering how sentences are properly formed the students proceed to learn how to write paragraphs that include multiple ideas.

In this study, as in previous studies which have attempted to investigate students' reactions to teacher feedback, the instrument for collecting data from the sample group was a questionnaire. This data gathering instrument is the most common method used for collecting research data. It can provide a great deal of information in an economical form. It is also the simplest and the most time-saving technique. Questionnaires are more objective than other data gathering instruments because data obtained through questionnaires are gathered in a standardized way and can be analyzed and interpreted more easily than any other data gathering instruments (Phellas et al., 2011).

The questionnaire used in this research project was used in Ken's study (2004) to investigate students' preferences for and responses to teacher feedback. The questionnaire items were adapted from those used in Ferris's study (1995) which investigated students' reactions to teacher feedback in multiple-draft compositions and Leki's (1991) research on the preferences of ESL students for error correction. A copy of the questionnaire is provided in the Appendix. The questionnaire was administered by the teacher (researcher himself) to ensure that the response rate was high and to clarify any ambiguity that the participating students may have encountered. The teacher read all of 
the questionnaire items aloud to ensure that the content was clear to the participating students. Participants used a check mark to indicate the degree of their agreement with each of 12 statements in a 5-point Likert scale.

\section{Data Analysis \& Discussion}

The responses of the participating students to the questionnaire items were analyzed with Statistical Package for the Social Sciences (SPSS), version 16, a software package used for statistical analysis, to obtain descriptive statistics. The percentages and frequencies of students' responses were presented in tables (below) to show the patterns of their preferences.

As Table 1 illustrates, if the always and usually categories are combined, the responses to the first question show that about three-fourths of the students were prepared to reread their essays again after the teacher returned to them with corrections. None of the students responded with never to reading their essays again. This result indicates that most of the surveyed students were serious about learning how to write in the target language and willing to know more about the basics of the composing skill. Previous studies found teacher feedback an important part of teaching second/foreign language writing (Hyland and Hyland, 2006), and a helpful learning tool for students to understand the weak points of their writing, identify writing problems, and improve their writing competencies (Cai, 2011). Therefore, teachers should utilize feedback to encourage and advance student learning by focusing on growth rather than grading (Sadler, 1983). To maximize the role of teacher feedback in serving as guidance for eventual writing development, teachers need to: a) motivate students, b) model effective revision strategies, c) raise students' awareness about the importance of (re)seeing their texts from the reader's perspective, d) encourage students to reflect on and self-assess their own writing, and e) use appropriate writing tasks and activities for teaching and assessment (Barkaoui, 2007).

Table 1. How often do you re-read your composition after your teacher returns it to you? $(\mathrm{N}=86)$

\begin{tabular}{lll}
\hline Responses & Frequency & Percentage \\
\hline Always & 37 & 43.0 \\
Usually & 26 & 30.2 \\
Sometimes & 20 & 23.3 \\
Not very often & 3 & 3.5 \\
Never & -- & -- \\
\hline
\end{tabular}

Students' responses to the second question showed that almost all of them thought carefully about the teacher's comments and corrections which means they attached a great value to their teacher's written feedback. This result indicates that students consider feedback "a key element of the scaffolding provided by the teacher to build learner confidence and the literacy resources to participate in target communities" (Hyland \& Hyland, 2006, p. 83). Given that the participants in this experiment were required to revise their drafts and submit a second draft, it is not surprising that the vast majority of the participants reported paying attention to their own drafts as well as their teachers' corrective responses. Feedback on composition assignments can have a positive effect on students' thinking or behavior toward their work and focus their attention on the purpose of writing (Carless, 2006). Moreover, EFL student writers tend to pay great attention to teachers' comments on their preliminary drafts and are, generally, serious in getting insights from their teachers' feedback (Ferris, 1995). In addition to the pedagogical value of teacher response as a feedback indicator teacher response carries affective values of increasing motivation and building a supportive classroom climate in which most students develop a feeling that they have control over their own learning (Brookhart, 2008; Richards \& Lockhart, 1996).

Table 2. Do you think about your teacher's comments and corrections carefully? $(\mathrm{N}=86)$

\begin{tabular}{lll}
\hline Responses & Frequency & Percentage \\
\hline Always & 57 & 66.3 \\
Usually & 27 & 31.4 \\
Sometimes & 2 & 2.3 \\
Not very often & -- & -- \\
Never & -- & -- \\
\hline
\end{tabular}

Students' responses to questions 3-7 are summarized in table 3. The five questions addressed what kinds of feedback students paid more attention to. If the always and usually categories are combined, responses to the five 
questions reveal that the students paid more attention to feedback involving organization and grammar $(81 \%)$ and content/ideas (79\%). Students paid slightly less attention to feedback related to mechanics $(74.5 \%)$ and vocabulary (73\%). The high percentage of students who mentioned that they paid attention to their teachers' comments with regard to different aspects related to their writing indicates that the students perceived the importance of focusing on feedback that may help them improve their writing for future composition assignments. In particular, the majority of the participants seem to realize that feedback involving organization, grammar, and content improved their revised drafts. A considerable number of students considered feedback on vocabulary and writing mechanics (defined as spelling, punctuation and capitalization) to be important to their writing, suggesting that such feedback may be perceived by students as transcending the specifications of a particular assignment-information that they could apply to any future writing project (Ferris, 1995, p. 42).

Apparently, participants paid attention to comments on both types of errors; surface-level and meaning-level. Surface-level errors are related to errors in grammar, vocabulary, and mechanics, while meaning-level errors are concerned with weaknesses in content and organization. A possible explanation for this high attention to all five categories of teacher feedback is that the class teacher (the researcher himself) gave written comments on any inaccurate aspect in the students' writing. In addition, the teacher set aside time to talk to each student in class to explain the comments and gave suggestions on how to correct the mistakes. The teacher believes that providing constructive feedback to students is required to help them improve their writing following a theoretical framework that maintains that students' errors, if not corrected, will fossilize and will become embedded in the functioning language patterns of the learners (Chastain,1990). Responding to students writing helped the teacher to address students' needs to have their errors corrected and commented which is a key motivational element and a significant component for quality education that help them pay more attention, engage in working on different tasks, and appear to be happy and eager to learn.

Table 3. Questions 3-7: How often do you pay attention to the comments and corrections involving ...? $(\mathrm{N}=86)$

\begin{tabular}{|c|c|c|c|c|c|c|c|c|c|c|}
\hline \multirow{2}{*}{$\begin{array}{l}\text { Questionnaire } \\
\text { item }\end{array}$} & \multicolumn{2}{|c|}{ Always } & \multicolumn{2}{|c|}{ Usually } & \multicolumn{2}{|c|}{ Sometimes } & \multicolumn{2}{|c|}{ Not very often } & \multicolumn{2}{|c|}{ Never } \\
\hline & No. & $(\%)$ & No. & $(\%)$ & No. & $(\%)$ & No. & $(\%)$ & No. & $(\%)$ \\
\hline Organization & 40 & $(46.5)$ & 30 & $(34.9)$ & 15 & $(17.4)$ & 1 & $(1.2)$ & -- & -- \\
\hline Content/ideas & 45 & $(52.3)$ & 23 & $(26.7)$ & 15 & $(17.4)$ & 3 & (3.5) & -- & -- \\
\hline Grammar & 49 & $(56.9)$ & 21 & $(24.4)$ & 14 & $(16.3)$ & 2 & $(2.3)$ & -- & -- \\
\hline Vocabulary & 34 & $(39.4)$ & 29 & $(33.7)$ & 22 & $(25.6)$ & 1 & $(1.2)$ & -- & -- \\
\hline Mechanics & 36 & (41.9) & 28 & $(32.6)$ & 16 & $(18.6)$ & 5 & $(5.8)$ & 1 & $(1.2)$ \\
\hline
\end{tabular}

Questions 8-12 assessed the perspectives of student writers on how important they feel it is to receive teacher feedback on the different aspects of their writing. Responses to the five questions are summarized in Table 4 . The results show that participants felt that all feedback types were important to them. In particular, feedback on grammar has been ranked as the most important type of comment that the students expect to receive from their teachers. If the very important and quite important categories are combined, $80 \%$ of the participants reported that feedback on grammar is important to them, followed by feedback on both organization and content (78\%) and then feedback on both vocabulary and mechanics $(75.6 \%)$. These findings indicate that three-fourths or more of the student writers considered their teacher comments to be of great value. The reactions of students toward their teachers' feedback has been classified as a decisive factor that influences the usefulness of the given feedback and provides student writers with ample opportunities to experience the process of discovering what they want to express in subsequent revisions (Ferris, 2003; McGarrell \& Verbeem, 2007).

Previous studies on student response to teacher feedback yielded similar results. The observed preference for grammar feedback is consistent with the findings of McCurdy (1992), Hedgcock and Lefkowitz (1994) where students reported that grammar (in addition to content and organization) were very important to their progress as writers. Ferris (1995) found that ESL students paid attention more to teachers' comments on grammar than those on other areas and felt that teachers' feedback had helped them to improve their writing. Other studies that investigated the effects of different types of teacher feedback on students' revisions found that students can improve their writing in situations where constructive comments regarding their local and global errors are given simultaneously (Fathman \& Whalley, 1990). In addition to giving the students comments on different types of their writing throughout the semester, the teacher gathered the students' mistakes in each assignment, retyped them in an MS word document and distributed copies to all of the participants. Then, the teacher devoted time in the following class and asked the students to take turns in going through those mistakes and correcting them. In some cases, the teacher asked the students to write the sentences with errors on the board in order to make it clear how 
those errors are corrected. The students had to write the correct forms beside all the errors in the document to make sure that they recognized errors on their own internalized the process of revision rather than allowing student writers to simply copy the corrections into their subsequent drafts or final copies. Instead, students were made to understand why the errors were indicated in the feedback as well as record and study the mistakes noted by the teacher in order to make the feedback positive and effective (Fregeau, 1999).

Table 4. Questions 8-12: How important is it to you for your English teacher to give you comments on. . .? $(\mathrm{N}=86)$

\begin{tabular}{lllllllllll}
\hline \multirow{2}{*}{$\begin{array}{l}\text { Questionnaire } \\
\text { item }\end{array}$} & \multicolumn{2}{l}{ Very important } & \multicolumn{2}{c}{ Quite important } & \multicolumn{2}{c}{ Okay } & \multicolumn{3}{c}{ Not important } & \multicolumn{2}{c}{ Not important at all } \\
\cline { 2 - 11 } & No. & $(\%)$ & No. & $(\%)$ & No. & $(\%)$ & No. & $(\%)$ & No. & $(\%)$ \\
\hline Organization & 60 & $(70)$ & 7 & $(8)$ & 14 & $(16.3)$ & 4 & $(4.7)$ & 1 & $(1.2)$ \\
Content/ideas & 46 & $(53.5)$ & 21 & $(24.4)$ & 17 & $(20)$ & 2 & $(2.3)$ & -- & -- \\
Grammar & 56 & $(65.1)$ & 13 & $(15)$ & 14 & $(16.3)$ & 3 & $(3.5)$ & -- & -- \\
Vocabulary & 41 & $(47.7)$ & 24 & $(28)$ & 15 & $(17.4)$ & 5 & $(5.8)$ & 1 & $(1.2)$ \\
Mechanics & 47 & $(54.7)$ & 18 & $(21)$ & 15 & $(7.4)$ & 5 & $(5.8)$ & 1 & $(1.2)$ \\
\hline
\end{tabular}

\section{Summary and Recommendations}

This study investigated the perspectives of Saudi ESL freshmen towards their teachers' response to their writing. Eighty six participants responded to a questionnaire that had been used in previous studies. The aim of the study was to shed light on the factors that influence students' attitudes about writing in English as a foreign language. The study found that students were willing to read their essays again after the teacher commented on them which could indicate that they attached a great value to their teacher's written comments to facilitate developing the necessary skills of writing in a foreign language. Moreover, most of the surveyed students asserted that they thought carefully about teacher's comments and corrections, which is an indication that those students were interested in learning from their teacher response to help them gain confidence in themselves as good writers. The fact that participating students mentioned that they paid attention to teacher response on both surface-level errors and meaning-level errors implies that they found their teacher response effective in helping them produce better writing with fewer mistakes. The participants mentioning that all types of teacher response are important to them and may be considered a sign of positive attitudes toward such responses on their writing and their role in developing the necessary skills to improve their writing proficiencies.

Writing teachers should remember that their responses to students' writing, as well as peer response, are basic components of the process approach to teaching writing. The process approach has been defined as "an approach that emphasizes teaching writing, not as product, but as process; helping students discover their own voice; allowing students to choose their own topic; providing teacher and peer feedback; encouraging revision and using student writing as the primary text of the course" (Matsuda, 2003: 67). Therefore, students in writing classrooms should be encouraged to work together and receive feedback from each other to facilitate the development of their composition skills. Alqurashi (2009) examined Saudi male college students' attitudes towards peer feedback and found that most of them had positive attitudes towards both giving and receiving comments and advice from their peers and thought that their writing skills improved as a result of engaging in peer response groups. In addition, the recursive nature of building composition skills should be clear to writing teachers. When students write, they are engaged in a recursive process that involves six distinct steps: prewriting, drafting, responding, revising, editing and publishing (Harris \& Graham, 1996). Accordingly, writing is not an orderly sequence of discrete activities. Rather, it is a recursive process that puts a special emphasis on the learner and learner needs and highlights certain overlapping steps that student writers have to go through. Students should be encouraged to return to any of the composing steps at any time during the writing process in order to find new ideas, think about new ways of organizing them, and imagine new ways of expressing them.

Feedback to student writers can be useful as a motivating factor to help students revise their writing several times in order to produce improved pieces of writing (Russell \& Spada, 2006). For students to understand their mistakes, learn from their errors, and write more smoothly and accurately, they need to receive productive feedback that points out errors or mistakes, directly or indirectly, and provides the correct form (Panova \& lyster, 2002). The absence of feedback or providing vague comments can be demotivating, or even frustrating, to students who regard teacher comments as guidelines to monitor their writing progress. Unclear feedback, or a lack thereof, may misdirect student writers and give them the wrong impression of their performance and progress (Lee, 2008). If this situation continues, students may develop the assumption that they have become proficient writers and can effectively communicate their ideas. They also may not perceive the need to revise the substance of their texts 
which may lead them to experience 'errors fossilization', making it difficult to eliminate these errors later on (Brookhart, 2008). Writing teachers are required to provide focused responses to student writing that take into account the goals of a particular writing course and the level of students' L2 proficiency to assure that they can properly interpret the comments. Also, writing teachers should not overstress the correction of surface errors because this may lead to the passive action of copying teacher corrections into revisions without understanding how to identify and correct errors on their own. In order to maximize the value of feedback, student-teacher conferences should be held regularly which both allow teachers to gain a deeper understanding of student's individual problems and students to express their worries more amenably and ask for clarifications on any comments made by the teachers.

The responsibility of teachers to provide constructive feedback to student writing in their multiple drafts is considered to be an extra work load in addition to their teaching load and office hours. Reading 20-30 essays, or even more, for every composition assignment, evaluating content, correcting mistakes, and providing valuable feedback can be a burden that negatively affects writing teachers' performance if not balanced with other responsibilities. Writing teachers often complain that the process of reading and responding to student composition assignments is time-consuming and leads, in most cases, to an increase in their workload. Many teachers find themselves unable to respond to student writing as often as they would wish (Burstein, 2004). Other work obligations, such as serving in accreditation committees and participating in the process of academic advising, consume faculty time and influence them to limit themselves to lecture-focused methods of teaching where responding to student writing is not a significant priority. Adequate institutional support should be present in order to ease these difficulties. For example, the number of students in each section should be limited to $12-15$ in order to help teachers allocate enough time for each student. Moreover, academics need their work to be recognized and supported in order to be motivated to continue their own efforts. When higher education institutions fail to positively respond to these needs, academics are discouraged and face a more career risks such as not having time to do the research and publishing required for promotions and advancement.

\section{References}

Ababneh, S. (2012). Motivation and attitudes of vocational education female students toward learning English. International Journal of Vocational Education and Training, 20(1), 42-52.

Alqurashi, F. (2009). Saudi students' reactions to peer response groups in EFL composition classrooms. Journal of King Saud University-Languages and Translation, 21, 57-67

Applebee, A. N. (1986). Problems in process approaches: Toward a reconceptualization of process instruction. In A. Petrosky \& D. Bartholomae (Eds.), The teaching of writing (pp. 95-113). Chicago: The National Society for the Study of Education.

Arndt, V. (1993). Response to writing: Using feedback to inform the writing process. In M. Brook \& L. Walters (Eds.), Teaching composition around the Pacific rim: Politics and pedagogy (pp. 90-116). Clevedon, UK: Multilingual Matters.

Ashwell, T. (2000). Patterns of Teacher response to student writing in a multiple-draft composition classroom: Is content feedback followed by form feedback the best method? Journal of Second Language Writing, 9, 227-257. http://dx.doi.org/10.1016/S1060-3743(00)00027-8

Asiri, I. (1996). University EFL Teachers' Written Feedback on Compositions and Students' Reactions (Unpublished doctoral dissertation). University of Essex, Colchester.

Barkaoui, K. (2007). Revision in second language writing: What teachers need to know. TESL Canada Journal, 25(1), 81-92.

Block, D. (2003). The social turn in second language acquisition. Edinburgh: Edinburgh University Press.

Brookhart, S. M. (2008). How to give effective feedback to your students. Alexandria, VA: Association for Supervision and Curriculum Development.

Burstein, J., Chodorow, M., \& Leacock, C. (2004). Automated essay evaluation: The criterion online writing service. AI Magazine, 25(3), 27.

Cai, J. (2011). A contrastive study of online peer feedback and online teacher feedback in teaching English writing to college students. Foreign Language World, 134(2), 65-72.

Carless, D. (2006). Differing perceptions in the feedback process. Studies in Higher Education, 31(2), 219-233. http://dx.doi.org/10.1080/03075070600572132 
Chaistain, K. B. (1990). Characteristics of graded and ungraded compositions. The Modern Language Journal, 74, 10-14. http://dx.doi.org/10.1111/j.1540-4781.1990.tb02547.x

Cheng, M., \& Banya, K. (1997). Bridging the gap between teaching styles and learning styles. In J. Reid (Ed.), Understanding Learning Styles in the Second Language Classroom (pp. 80-84). Prentice Hall.

Cohen, A. D. (1987). Student processing of feedback on their compositions. In A. L. Wenden \& J. Rubin (Eds.), Learner strategies in language learning (pp. 57-69). Englewood Cliffs, N. J.: Prentice-Hall.

Cohen, A. D. (1991). Feedback on writing: The use of verbal report. Studies in Second Language Acquisition, 13(2), 133-157. http://dx.doi.org/10.1017/S027226310000992X

Fathman, A. K., \&Whalley, E. (1990). Teacher response to students' writing: Focus on form versus content. In B. Kroll (Ed.), Second language writing: Research insights for the classroom (pp. 177-190). Cambridge: Cambridge University Press. http://dx.doi.org/10.1017/CBO9781139524551.016

Ferris, D. R. (1995). Student reactions to teacher response in multiple-draft composition classrooms. TESOL Quarterly, 29(1), 33-53. http://dx.doi.org/10.2307/3587804

Ferris, D. R. (2003). Response to student writing: Implications for second language students. Mahwah, NJ: Lawrence.

Fregeau, L. A. (1999). Preparing ESL students for college writing: Two case studies. The Internet TESL Journal, 5(10). Retrieved from http://iteslj.org/Articles/Fregeau-CollegeWriting.html

Goldstein, L. (2001). For Kyla: What does the research say about responding to ESL writers. In T. Silva \& P. Matsuda (Eds.), On second language writing (pp. 73-90). Mahwah, NJ: Lawrence Erlbaum.

Grami, M. (2005). The effect of teachers' written feedback on ESL students' perception: a study in a Saudi ESL university-level context. Annual Review of Education, communication and Language Sciences, 2.

Hammond, J. (Ed.). (2002). Scaffolding teaching and learning in language and literacy education. Newtown: PETA.

Hamp-Lyons, L., \& Chen, J. (2001). An investigation into the effectiveness of teacher feedback on student writing. In D. Kember, S. Candlin, \& L. Yan (Eds.), Further case studies of improving teaching and learning from the Action Learning Project. Hong Kong: Action Learning Project. Retrieved from http://celt.ust.hk/files/public/3e207-220.pdf

Harris, K. R. \& Graham, S. (1996). Making the writing process work: Strategies for composition and self-regulation. Cambridge, MA: Brookline Books.

Hashim, H. H. (2011). Peer Feedback with Checklists in Writing Classes: Saudi learners' and teachers' attitudes and perceptions (Unpublished master's thesis). King Saud University, Riyadh. Retrieved from http://repository.ksu.edu.sa/jspui/bitstream/123456789/19286/1/\%D8\%A7\%D9\%84\%D8\%B1\%D8\%B3\% D8\%A7\%D9\%84\%D9\%87.pdf

Hedgcock, J., \& Lefkowitz, N. (1994). Feedback on feedback: Assessing learner receptivity in second language writing. Journal of Second Language Writing, 3, 141-163. http://dx.doi.org/10.1016/1060-3743(94)90012-4

Hino, J. (2006). Linguistic information supplied by negative feedback: A study of its contribution to the process of second language acquisition (Unpublished doctoral dissertation). University of Pennsylvania.

Hyland, F. (2001). Providing effective support: Investigating feedback to distance language learners. Open Learning, 16(3), 233-247. http://dx.doi.org/10.1080/02680510120084959

Hyland, K., \& Hyland, F. (2006). Feedback in second language writing: Contexts and issues. Cambridge: Cambridge University Press. http://dx.doi.org/10.1017/CBO9781139524742

Jacobs, G. M., \& Farrell, T. S. C. (2001). Paradigm shift: Understanding and implementing change in second language education. TESL-EJ, 5(1). Retrieved from http://tesl-ej.org/ej17/a1.html

Ken, C. K. (2004). An Investigation into Students' preferences for and responses to teacher feedback and its implications for writing teachers. Hong Kong Teachers' Centre Journal, 3. Retrieved from http://edb.org.hk/HKTC/download/journal/j3/10.pdf

Kern, R. G. (1995). Students' and teachers' beliefs about language learning. Foreign Language Annals, 28(1), 71-92. http://dx.doi.org/10.1111/j.1944-9720.1995.tb00770.x 
Kroll, B. (2001). Considerations for teaching an ESL/EFL writing course. In M. Celce-Murcia (Ed.), Teaching English as a second or foreign language (3rd ed., pp. 219-232). Boston, MA: Heinle and Heinle.

Lantolf, J. (Ed.). (2000). Sociocultural theory and second language learning: Recent advances. Oxford: Oxford University Press.

Lazar, G., \& Ellis, E. (2002). Genre as Implicit methodology in a collaborative writing initiative. IJES, 2(1), $155-168$.

Lee, I. (2005). Error correction in the L2 writing classroom: What do students think? TESL Canada Journal, 22(2), $1-16$.

Lee, I. (2008). Understanding teachers' written feedback practices in Hong Kong secondary classrooms. Journal of Second Language Writing, 17, 69-85. http://dx.doi.org/10.1016/j.jslw.2007.10.001

Leki, I. (1991). The preferences of ESL students for error correction in college-level writing classes. Foreign Language Annals, 24, 203-218. http://dx.doi.org/10.1111/j.1944-9720.1991.tb00464.x

Littleton, C. E. (2011). The Role of feedback in two fan fiction writing Groups (Unpublished doctoral dissertation). Indiana University of Pennsylvania.

Mahfoodh, O., \& Pandian, A. (2011). A Qualitative case study of EFL students'affective reactions to and perceptions of their teachers' written feedback. English Language Teaching, 4(3), 14-25. http://dx.doi.org/10.5539/elt.v4n3p14

Marjan, S., \& Farhad, T. (2014). The effects of two types of oral feedback on Iranian EFL learners' essay writing. International Journal of Language Learning and Applied Linguistics World, 7(1), 132-142.

Matsuda, P. K. (2003). Process and post-process: A discursive history. Journal of Second Language Writing, 12, 65-83. http://dx.doi.org/10.1016/S1060-3743(02)00127-3

McCurdy, P. (1992, March). What students do with composition feedback. Paper presented at the 27th Annual TESOL Convention, Vancouver, B. C.

McGarrell, H., \& Verbeem, J. (2007). Motivating revision of drafts through formative feedback. ELT Journal, 61, 228-236. http://dx.doi.org/10.1093/elt/ccm030

Mustafa, R. F. (2012). Feedback on the feedback: Sociocultural interpretation of Saudi ESL learners' opinions about writing feedback. English Language Teaching, 5(3), 3-15. http://dx.doi.org/10.5539/elt.v5n3p3

Myers, S. (1997). Teaching writing as a process and teaching sentence-level syntax: Reformulation as ESL $\begin{array}{lllll}\text { composition } & \text { feedback. } & T E S L-E J, & \text { 2(4). } & \text { Retrieved }\end{array}$ http://www.cc.kyoto-su.ac.jp/information/tesl-ej/ej08/a2.html

Myles, J. (2002). Second Language Writing and Research: The Writing Process and Error Analysis in Student Texts. TESL-EJ, 6(2). Retrieved from http://tesl-ej.org/ej22/a1.html

Myles, J. (2002). Second language writing and research: The writing process and error analysis in student texts. TESL-EJ, 6(2). Retrieved from http://tesl-ej.org/ej22/a1.html

Oladejo, J. A. (1993). Error correction in ESL: Learners' preferences. TESL Canada Journal, 10(2), 71-89.

Panova, I., \& Lyster, R. (2002). Patterns of corrective feedback and uptake in an adult ESL classroom. TESOL Quarterly, 36(4), 573-595. http://dx.doi.org/10.2307/3588241

Phellas, C. N., Bloch, A., \& Seale, C. (2011). Structured methods: Interviews, questionnaires and observation. In C. Seale (Ed.), Researching Society and Culture (pp. 181-205). London: Sage.

Prior, P. (2006). A sociocultural theory of writing. In C. A. MacArthur, S. Graham, \& J. Fitzgerald (Eds.), Handbook of writing research (pp. 54-66). New York: The Guilford Press.

Reid, J. M. (1993). Teaching ESL Writing. New Jersey: Regents/Prentice Hall.

Richards, J. C., \& Lockhart, C. (1996). Reflective teaching in second language classrooms. Cambridge, England: Cambridge University Press.

Russell, J., \& Spada, N. (2006). The effectiveness of corrective feedback for the acquisition of L2 grammar: A meta-analysis of the research. In J. Norris \& L. Ortega (Eds.), Synthesizing research on language learning and teaching (pp. 133-164). Amsterdam: John Benjamin Publishing.

Sadler, D. (1983). Evaluation and improvement of academic learning. Journal of Higher Education, 54(1), 60-79. http://dx.doi.org/10.2307/1981645 
Saito, H. (1994). Teachers' practices and students' preferences for feedback on second language writing: A case study of adult ESL learners. TESL Canada Journal, 11(2), 46-70.

Scane, J., Guy, A. M., \& Wenstrom, L. (1991). Think, write, share: Process writing for adult ESL and basic education students. Toronto, Canada: OISE Press.

Sommers, N. (1982). Responding to student writing. College Composition and Communication, 33, 148-156. http://dx.doi.org/10.2307/357622

Weihong, W., \& Yuanxing, D. (2010). The Justification of teacher-guided error correction of Chinese college students' English writing. Chinese Journal of Applied Linguistics, 33(3), 63-75.

Zamel, V. (1985). Responding to student writing. TESOL Quarterly, 19(1), 79-99. http://dx.doi.org/10.2307/3586773

Zhang, S. (1995). Re-examining the affective advantages of peer feedback in the ESL writing classroom. Journal of Second Language Writing, 4, 209-222. http://dx.doi.org/10.1016/1060-3743(95)90010-1

\section{Copyrights}

Copyright for this article is retained by the author(s), with first publication rights granted to the journal.

This is an open-access article distributed under the terms and conditions of the Creative Commons Attribution license (http://creativecommons.org/licenses/by/3.0/). 